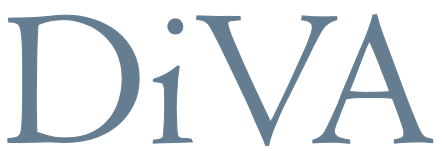

http://uu.diva-portal.org

This is an author produced manuscript (pre-print version) of a paper.

Citation for the manuscript:

Hall, Jonathan

"Are Migrants More Extreme Than Locals After War? : Evidence From a Simultaneous Survey of Migrants in Sweden and Locals in Bosnia"

URL: http://urn.kb.se/resolve?urn=urn:nbn:se:uu:diva-198762 


\section{Are Migrants More Extreme than Locals After War? Evidence from a Simultaneous Survey of Migrants in Sweden and Locals in Bosnia}

\section{Introduction}

Analysts survey the local populations of conflict-affected countries in order to measure support for conflict resolution and transitional justice initiatives, reconciliation, political tolerance, and the factors enabling or inhibiting them (2010; Brounéus 2008; Canetti-Nisim et al. 2009; Gibson 2004; Gibson, Sonis, and Hean 2010; Halperin and Bar-Tal 2011; Kostić 2007; Pham et al. 2007; Thoms, Ron, and Paris 2010). However, we seem to know very little about the attitudes of migrant populations originating from, but external to, places such as the former Yugoslavia, Rwanda or Sri Lanka. This is a problem since migrants are often perceived as more extreme than local populations, while at the same time having an important influence on the situation back home.

This paper helps to fill this lacuna by examining a key assumption in the literature: that migrants harbor more conflictive attitudes than locals after war (Anderson 1998, 74; Anderson 1999, 18; Bigombe, Collier, and Sambanis 2000, 333-334; Bock-Luna 2007, 15; Collier 2000, 851; Collier et al. 2003, 85-86; Collier and Hoeffler 2004, 575; 2006, 24; 2007, 797; Golan and Gal 2009, 127; Ignatieff 2001; Kaldor 2001, 85; Kaldor-Robinson 2002, 181; Lyons 2006, 128; 2007, 545; Newman 2006, 96; Shain 2007, 115; Turner 2008, 753; Wennmann 2007, 434). ${ }^{1}$ This assumption is applied equally to migrants in neighboring states and further afield (typically Europe and North America). At least four reasons are offered in the literature to explain differences between migrants and locals: 1) being removed from the situation, migrants have less realistic perceptions of the conflict; 2) migrants either do not pay the costs of war directly, or face fewer opportunity costs than locals in promoting a hard line; 3 ) being physically separated from the nation

\footnotetext{
${ }^{1}$ Terms such as "migrants", "immigrants" and "diasporas" are used differently across disciplines. In this literature, they tend to be used interchangeably to denote cross-border migrants who maintain emotional and social ties with the homeland (Brubaker 2005; see also Van Hear 1998). Their meanings converge partly because descendants of those who migrate may be perceived as migrants or immigrants in their host societies (Sheffer 2003, 16). I use the term "migrants" in this broad and multigenerational sense.
} 
while living as minorities in their host societies, migrants benefit psychologically from maintaining their collective identity and homeland connection, which are imprinted with collective traumas, sectarian ideologies and territorial attachments; 4) following a peace agreement, local populations may become less polarized as they strive to rebuild their common lives, meanwhile migrants preserve the past, avoid contact with former rival groups and more easily harbor animosities.

However, the evidence offered in support of such claims is indirect, drawing upon case studies that illustrate migrant networks' links with insurgencies and refugee recruitment (Lischer 2005; Zolberg, Suhrke, and Aguayo 1989), diaspora mobilization (Adamson 2005, 2006; Fair 2005; Hockenos 2003; Wayland 2004) and cross-national, aggregate-level research on the impact of remittances (Collier and Hoeffler 2004) and refugee flows (Salehyan 2007, 2009; Salehyan and Gleditsch 2006). Until now, no one has attempted to systematically compare the attitudes of migrants and locals after war directly.

This paper offers several contributions. First, it reviews previous research, underscoring its tendency to portray migrants as holding uncompromising views although we lack the micro-level data necessary to validate claims about migrant attitudes. Secondly, it develops an alternative theoretical perspective. In essence, life on the outside may have an upside; migrants are less exposed to difficult wartime and post-war conditions as well as the societal communication that reflects and disseminates beliefs developed to cope with conflict and sustain the war effort (Bar-Tal 2000). Life in settlement countries is not without hardship. However, the coping strategies migrants employ to manage the stress of acculturation and displacement, including nostalgia, may reduce their need for defensive psychological resources, which in turn give rise to conflictive beliefs (Juhl et al. 2010; Routledge et al. 2011; Sedikides et al. 2009). Moreover, coping positively with trauma requires a certain detachment from "reality" and the development of specific "illusions" (Taylor 1983). Being removed from daily life in conflict-affected societies, migrants may nurture more peaceful attitudes about what led to traumatic events, what is necessary to prevent their reoccurrence and the nature of former adversaries.

Thirdly, this paper offers a straightforward comparison of the conflictrelated attitudes of migrants in Sweden and locals in Bosnia ${ }^{2}$. In the analysis I first present cross-tabulations of responses to identical questions posed in simultaneous surveys in 2010. This is a first look at the new data. Next, I use regression analysis to control for a rich set of individual background characteristics such as personal experiences during war, urban background and educational attainment.

\footnotetext{
${ }^{2}$ This paper refers to Bosnia and Herzegovina as simply "Bosnia".
} 
The conflicts that followed the breakup of Yugoslavia eventually coalesced in the Bosnian War (1992-95), generating a massive refugee crisis. It is estimated that 38 percent of Bosnia's population currently lives outside its borders (Valenta and Ramet 2011). Despite its small population size, Sweden was the third largest recipient of these refugees in Europe and now hosts one of its largest emigrant communities. Comparing migrants in Sweden with locals in Bosnia is theoretically interesting for several reasons. First, prominent scholars use migrants situated in the wealthy, liberal and democratic states of Europe and North America as examples (Anderson 1998; Collier and Hoeffler 2004; Duffield 2001; Kaldor 2001; Lyons 2006). Second, most came to Sweden as a result of the war and are thus "conflictgenerated" (Lyons 2007) or "persecuted refugees" (Lischer 2005) with ample reason to harbor animosities. Third, Bosnia is the main theory-building case for the influential "new wars" theory. From this perspective, far off migrant communities often play a prominent role in fueling contemporary conflicts because they "...find solace in fantasies about their origins which are often far removed from reality" (Kaldor 2001, 85). Fourth, following a peace agreement it is believed that locals tend to favor peace while migrants "preserve their own hatreds" and "slow the healing process" (Collier and Hoeffler 2004, 575, 589). Nearly seventeen years have passed since the Dayton accords were signed, ending the war in Bosnia. Comparing the attitudes of migrants in Sweden with locals in Bosnia provides the ability to examine these claims directly using micro-level data.

The following section reviews previous research. Next, an alternative perspective on attitudinal differences between migrants and locals is developed. This is followed by the empirical analysis and subsequently the final discussion.

\section{Review of Previous Research}

State borders and political communities do not perfectly overlap. This situation is viewed as potentially explosive when violence targets entire groups and causes mass displacement (Lischer 2005). It has long been held that nationalist sentiments are strongest among migrants; a view expressed by Lord Acton's familiar aphorism "exile is the nursery of nationalism" (Acton 1967, 146; quoted in Anderson 1998, 59). Experiences of victimization engender grievances among the displaced, motivating support for violence and shaping the collective identities of migrants beyond the reach of the state they fled (Collier and Hoeffler 2004; Lischer 2005; Lyons 2006; Stedman and Tanner 2003; Zolberg, Suhrke, and Aguayo 1989).

Being removed from the local conflict situation has two potential implications. First, the beliefs they share are seen as less nuanced than those of the local population. Those settled abroad may develop "perceptions of the 
homeland that are frozen in time or distorted by nostalgia rather than recent experience" (Lyons 2007, 533), leading to more categorical and uncompromising attitudes and territorial attachments (Lyons 2006, 128). Meanwhile, refugees isolated in camps may become the captive audience of manipulative leaders who "...exaggerate or distort the nature of the violence that caused the displacement" (Lischer 2008, 100; see also Stedman and Tanner 2003). Second, migrants either do not pay the costs of conflict directly or face fewer opportunity costs in joining the fight. Those located in wealthier countries have resources to spare, meanwhile their political activities do not put themselves in harms way (Anderson 1998, 74; Collier and Hoeffler 2004, 575). At the same time, disaffected populations living in poor conditions in refugee camps are fertile grounds for recruits (Salehyan 2009; Zolberg, Suhrke, and Aguayo 1989).

This attitudinal gap between migrants and locals is thought to widen following a peace agreement. Migrants who settle abroad may respond to assimilatory pressures and a sense of loss of heritage by maintaining their collective identity and link with the lost nation (Smith 1986, 152). In conflictgenerated communities, this may preserve conflictive myths, symbols and political ideologies (Lyons 2006; Turner 2008, 761). In neighboring countries, a lack of will on the part of host governments, great powers and international actors to find a solution to the refugee crisis may make "temporary" camps permanent fixtures and contribute to refugee radicalization (Adelman 1998). While migrants remain polarized and have little contact with their adversaries (Turner 2008, 752), locals may experience a "peace dividend" and incentives to compromise, reconcile and forge a common life (Collier and Hoeffler 2004).

The claim that migrants are less compromising than locals after war is based largely on indirect evidence rather than attitudinal research. As case studies of regional conflicts in Central Asia, former Yugoslavia and the Great Lakes region of Africa illustrate, refugee flows create cross-border networks that facilitate the spread of ideology, arms and fighters and provide a basis for recruitment (Byman et al. 2001, Ch. 4; Harpviken 2009; Lischer 2005; Zolberg, Suhrke, and Aguayo 1989). Examples such as movements for an independent Kosovo, Kurdistan and Tamil Eelam attest that migrant communities settled further abroad in, for example, Europe and North America extend these transnational networks further, providing considerable financial and human resources to rebels (Adamson 2005; Byman et al. 2001, Ch. 3; Fair 2005; Wayland 2004). Large-N cross-national studies lend support to this view. Refugee flows may lead to conflict contagion and thus partly account for why conflicts cluster in space (Salehyan 2006; Salehyan and Gleditsch 2006), while the presence of refugees across the border may prolong conflict in their country of origin (Salehyan 2007). At the same time, large diaspora communities situated abroad are believed to be associated with an increased risk of civil war recurrence (Collier and Hoeffler 
2004). ${ }^{3}$ In sum, the view that migrants provide strategic resources to rebels is taken as evidence of their willingness to support violence.

However, within this literature it is also acknowledged that most refugee crises do not result in refugee militarization (Adelman 1998; Salehyan and Gleditsch 2006, 361; Stedman and Tanner 2003) and that diasporas also engage in peaceful politics (Lyons 2007; Salehyan 2009, 34). At the same time, new research has begun to document the peace-promoting impact of migrants in various phases of armed conflict and conflict resolution (Brinkerhoff 2006; Caarls, Fransen, and Ruben 2012; Cochrane 2007; Cochrane, Baser, and Swain 2009; Horst 2008; Orjuela 2008; Smith and Stares 2007). Nevertheless, civil war research still largely conceives of migrants in terms of the risks they pose; a view reflected in recent reviews of the literature (Blattman and Miguel 2010, 29-30; Fearon 2011, 41; Golan and Gal 2009, 127; Hoeffler 2012, 23). Part of the problem lies in a mismatch between theory and data. ${ }^{4}$ Empirically, we simply lack the micro-level data necessary to validate theoretical claims regarding migrant attitudes (Salehyan 2007, 136). Theoretically, there is also a need for a careful treatment of the implications of 1) outward migration from conflict-affected countries and 2) life in settlement countries for the conflict-related attitudes of migrants. This is the subject of the following section.

\section{The Attitudes of Migrants and Locals After War: A New Perspective}

This section provides an alternative perspective on the differing attitudes migrants and locals may develop about conflict and why. First it describes the local context in which a conflictive ethos emerges in response to war and the implications outward migration has for the conflict-related perceptions of migrants. Next, it describes the implications of life in settlement countries. In particular, it highlights the importance of nostalgia as a coping resource. Finally, it examines how migration may bolster rather than undermine the ability to cope positively with traumatic experiences and reduce the need for defensive psychological resources that give rise to conflictive beliefs.

The fact that migrants are not exposed to the daily realities locals endure may have an upside. Violent conflicts often pit entire social groups against one another and entail psychological processes that reach beyond political

\footnotetext{
${ }^{3}$ However, the work of Paul Collier, Anke Hoeffler and co-authors on diasporas and civil war risk has been criticized on theoretical and methodological grounds (Sambanis 2002; Tarrow 2007).

${ }^{4}$ For example, the widely cited analysis by Collier and Hoeffler is characterized by a disjuncture between micro-level theory (diasporas "preserve their own hatreds" and thus "finance rebellion") and macro-level data (the ratio of the foreign born population in the United States to the local population as an indicator of "rebel finance").
} 
elites to affect the whole of society. Conflicts escalate through delegitimizing and dehumanizing discourses that invoke the collective myths and symbols of group identity (Kelman 1997). The social behavior emerging from this process produces new collective traumas and shared emotions such as fear and anger justifying revenge (Long and Brecke 2003, 28-29). Reconciliation after war entails a social-psychological process, distinguishable from conflict resolution among political elites, through which societal beliefs forming a conflictive ethos are replaced by those stemming from an ethos of peace (Bar-Tal 2000). However, scholars who study intractable conflicts find that beliefs developed to cope with conflict are difficult to change and often endure long after wars end. These involve themes such as the justness of one's goals, security, positive self-image, one's own victimization, delegitimization of opponents, patriotism, unity and peace (Bar-Tal 1998). Conflictive beliefs are in turn reflected in, as well as disseminated and validated by, societal communication, cultural products and symbols, while alternative sources of information are negatively sanctioned (Bar-Tal 2007). Even when peace agreements are reached, identity politics continue to present an important challenge to lasting peace.

Post-war political and economic conditions often exacerbate this situation. War wreaks long-term havoc on the economy and public health (Ghobarah, Huth, and Russett 2003). When states collapse, the local population may lack the capacity to rebuild on their own. External actors sometimes intervene in an attempt to build peace. However, they may end up contributing to "no war, no peace" situations by failing to address the conflict's root causes and to improve living standards, provide alternative employment for former combatants and fulfill the promise of reconstruction (Mac Ginty 2006). In some cases, intervention entails the external supervision of post-war political, economic and social policy in a way that ignores local agency. Local resistance may occur in the cultural domain and in the politics of collective memory (Kostić 2012).

Being physically removed from this setting may entail the development of different beliefs. According to Bar-Tal $(2000,72)$, "societal beliefs are dynamic, shared representations that reflect the political, economic and cultural conditions in a society. As the conditions change, so do the societal beliefs." When the local setting stagnates, migration may represent an exit from the spiral of societal conditions and symbolic politics that sustain a conflictive ethos among locals and make conflicts intractable. As migrants navigate life in their country of settlement, they may develop more peaceful attitudes in response to new surroundings.

Life in settlement countries is not without hardship. Migrants experience "acculturative stress" in reaction to their economic, cultural and social predicament and experiences such as downward occupational mobility, stereotypes, prejudice and discrimination (Sedikides et al. 2009, 383). Migrants may feel a sense of loss in relation to their original culture as well as loneli- 
ness and uncertainty about how to live life. Acculturative stress may be amplified by personal background. Migration due to "push" factors in countries of origin (e.g. refugees) is associated with higher stress levels among migrants than migration due to "pull" factors in settlement countries (e.g. economic migrants) (Sedikides et al. 2009, 363). Some argue migrants deal with these stresses by developing nostalgia for the past and preserving conflictive myths and memories of war as aspects of group identity (Anderson 1998; Collier and Hoeffler 2004; Hockenos 2003; Jaffrelot and Therwath 2007; Kaldor 2004; Kaldor-Robinson 2002; Lyons 2007). However, the literature on nostalgia suggests a very different view of its nature and functions as a psychological resource (Sedikides, Wildschut, Arndt, et al. 2008). Rather than reinforcing a sense of exile and victimization, nostalgia may enable migrants to move on from the traumatic past, reduce their reliance on defensive psychological resources and bolster their integration in settlement countries.

Nostalgia may enable migrants to successfully adapt to new surroundings. Davis $(1979,18)$ defines nostalgia as a "positively toned evocation of a lived past." Nostalgia creates meaning and coherence through story and arranges negative and positive elements of personal history as redemption, a narrative moving from an undesirable to a desirable state (Wildschut et al. 2006, 976). In this story, the self is viewed positively as the protagonist and in relation to significant others (friends, family members, etc.), momentous events and settings. Negative experiences are recollected but filtered through an "it was all for the best" attitude (Davis 1977, 418; cited in Wildschut et al. 2006, 976). Nostalgia is invoked to repair discontinuity between past and present (Sedikides, Wildschut, Gaertner, et al. 2008). By creating an awareness of being part of something greater, nostalgia imbues the present with meaning and alleviates feelings of existential threat (Routledge et al. 2008; Routledge et al. 2011). As a result, nostalgia provides a "reservoir of positive affect" with which migrants combat the negative emotions and sense of discontinuity produced by acculturative stress (Sedikides et al. 2009). By encouraging a positive outlook, openness to new experiences and an exploratory orientation, nostalgia increases sociality, facilitates new relationships and promotes the integration of migrants (Sedikides et al. 2009, 369).

Nostalgia may reduce the need to draw upon defensive psychological resources in response to crises. Group conflict and violent displacement serve as reminders of individual mortality and threaten self-esteem. As a psychological defense against the threat of physical annihilation and anxiety about death (Becker 1973) individuals cling to relationships, groups and beliefs that imbue their lives with purpose, stability and permanence (Juhl et al. $2010,310)$ Conflictive beliefs fulfill this purpose while at the same time reinforcing a positive self-image (Bar-Tal 2000; Solomon, Greenberg, and Pyszczynski 2000). However, if security needs are addressed by reflecting on the past, individuals may be less likely to develop exclusionary political 
attitudes or derogate out-groups as a way of dealing with "mortality salience" and promoting self esteem (Routledge et al. 2008, 138). By fortifying personal meaning (Routledge et al. 2008) and enhancing positive selfassociations (Vess et al. 2012), nostalgia promotes empathy for others (Zhou et al. 2012) and diminishes the need to, for example, defend group identity (Juhl et al. 2010) in order to restore a sense of equanimity.

The positive effects of nostalgia as a coping resource may be moderated by low perceptions of self-continuity over time (Iyer and Jetten 2011). Selfcontinuity entails the perception that past selves (e.g. social identities and relationships) are still relevant for the present (Sedikides et al. 2009). If the nostalgic view of the self is not relevant for life in the present, then nostalgia may backfire, serving instead as a painful reminder of what is now lost rather than a positive resource for coping (Iyer and Jetten 2011, 96). Having left the country of origin, one might assume that the sense of self-continuity would be weaker among migrants than among locals. However, following major crises such as wars and social revolutions, the local population may have low perceptions of self-continuity across pre-crisis and post-crisis periods as a result of the emergence of new economic and political conditions and the societal communication, cultural products and symbols that sustain a conflictive ethos. Perhaps ironically, because migrants do not experience day-to-day life during war and in post-war society their perceptions of prewar to post-war self-continuity, and by extension the positive effects of nostalgia, may be stronger in comparison to locals in conflict-affected countries. This view is not necessarily surprising, however, considering that migration may entail the improvement of one's ability to cope with trauma more generally.

Nostalgia is simply one example of the many psychological and material resources that may be available to migrants in the migration context. Generally speaking, migrants may be better positioned than locals to cope positively with traumatic experiences. Under certain conditions, life-threatening crises that challenge foundational assumptions about the world and one's place within it may result in personal growth and, through shared beliefs, positive social transformation (Janoff-Bulman 1992; Tedeschi and Calhoun 2004, 14). Like locals, migrants are exposed to the stresses of war indirectly (losing loved ones, having their property destroyed, or simply witnessing their homeland being torn apart by violence) and directly (being displaced by violence, physically wounded or imprisoned, or serving in fighting units). Developing a set of beliefs about the causes of these threatening events and one's ability to control them as well as a positive self-image is crucial for coping. But according to Taylor $(1983,1168)$, "The effective individual in the face of threat...permits the development of illusions, nurtures those illusions, and is ultimately restored by those illusions." Beliefs that enable positive coping involve a certain detachment from reality. The fact that migrants are not exposed to the daily realities of the local situation may support their 
psychological healing. More generally speaking, people with more personal and social resources are less likely to develop counterproductive coping behaviors like hostility towards out-groups (Canetti-Nisim et al. 2009; Hobfoll, Canetti-Nisim, and Johnson 2006). Increasing economic resources, for example, helps meet the demands posed by traumatic experiences and to see them not as debilitating but rather as challenges worthy of their time and investment (Antonovsky 1979). To the extent that migration increases access to such resources, it also enables moving on from the past.

In sum, migrants are external to the local context in which political and economic conditions and societal communication reinforce conflictive beliefs. Life in settlement countries is not without hardship. To manage the stress of acculturation and displacement, migrants may draw upon nostalgia. However, rather than trapping migrants in the traumas of the past, nostalgia may actually increase their ability to move on after crisis and encourage their integration in settlement countries. As a whole, to the extent that migration increases access to coping resources, it also lessens the need to employ defensive psychological resources such as conflictive beliefs.

\section{Data and Method}

To examine whether migrants hold more or less peaceful attitudes than locals after war, this paper compares the results of simultaneous surveys conducted among migrants in Sweden and locals in Bosnia during the spring of 2010. First, I present this data in the form of cross-tabulations in which national identity is held constant. Bosnia was formerly a unit of the Socialist Federal Republic of Yugoslavia, and today consists of three constituent nations: Bosniaks, Croats and Serbs. At the same time, many migrants surveyed identify as Yugoslavs (15 percent) and some as Swedes (2 percent). On both surveys, respondents were able to write in an alternative to these choices. Responses in this category were a handful of other minorities from the former Yugoslavia. For the sake of simplicity, regional minorities are presented along with Swedish respondents in the category "other". Because so many migrants identify as Yugoslavs, responses in this category are presented separately in the analysis. In the second part of the analysis, to further examine whether differences in attitudes are explained by the difference between being a migrant and a local I use regression analysis to control for a rich set of individual background characteristics.

\section{Sampling and Data Collection}

The survey of Bosnia was undertaken in cooperation with Ipsos, an established international firm, and is part of an ongoing long-term project to track 
societal reconciliation over time. Post-war census data is not available for Bosnia. Therefore, a stratified random sampling procedure is used to equally capture the attitudes of the three main ethnic groups (Bosniaks, Croats and Serbs) on the basis of three geographical strata defined by ethnic dominance. Sampling also reflects the urban and non-urban distribution of each population. Oral informed consent was obtained before interviews, which were conducted door-to-door by experienced staff of the same ethnicity as those interviewed. The survey covers the whole of Bosnia and has a response rate of 67 percent $(N=1500){ }^{5}$

Census data in Sweden do not include ethnicity. In the Swedish sample, the three ethnic strata are defined using Bosniak, Croat and Serb family names. ${ }^{6}$ Individuals were located by searching Sweden's online public listings. ${ }^{7}$ Because the listings are geo-referenced, the survey is able to capture the geographical distribution of Bosniaks, Croats and Serbs in Sweden. Searches using common family names return dozens of addresses. Individuals to contact were selected proportionally by location (city/village). The survey covers the whole of Sweden, however most migrants from the former Yugoslavia live in the major cities of Malmö, Gothenburg and Stockholm. The survey was translated into the native language of the respondents, included 71 questions and a cover letter providing basic information about the project, and was conducted by mail. This ensured the anonymity and informed consent of respondents. Of the 2580 individuals contacted by mail, 714 responded. ${ }^{8}$ This yielded a response rate of 28 percent.

A basic underlying assumption is that both surveys are representative. It is important to consider whether the higher unit non-response rate for the sample from Sweden will affect the results. The fact that survey response rates have been declining steadily over the past 40 years has generated significant research interest in the importance of non-response (Berinsky 2008). Numerous studies have shown that although respondents and nonrespondents may differ demographically in certain ways, correcting for nonresponse does not appear to substantially affect estimates of political opin-

\footnotetext{
${ }^{5}$ The survey was conducted first in Bosnia in 2005 and again in 2010. For further methodological details, see Kostić (2007).

${ }^{6}$ A door-to-door survey in Sweden was not feasible. Though there are "ethnic neighborhoods" in Sweden, migrants from the former Yugoslavia are not generally confined to them and instead live intermixed with other members of society throughout the country.

${ }^{7}$ www.eniro.se.

${ }^{8}$ Kostić and I conducted an initial pilot study to test out our survey guideline in the spring of $2008(N=16)$. Then, in the fall of 2008 we conducted an initial round of data collection by mail $(N=239)$. Finding that the procedure worked very smoothly, we then rolled out the rest of the survey during the spring of $2010(N=475)$. I find no significant differences in attitudes between the two samples collected by mail and thus include data from both rounds in the analysis $(N=714)$.
} 
ion. ${ }^{9}$ Broad reviews find that even surveys with relatively low response rates are highly representative of public opinion, and that improving response rates produces only modest returns in terms of representativeness (Holbrook, Krosnick, and Pfent 2007).

More unit non-response thus does not necessarily result in more response error. This is because non-response may be the result of a random process; that is, the factors that drive non-response may be uncorrelated with the variables of interest to the survey. Experiments conducted by the Pew Research Center (2012) show that respondents are more likely to engage in political and social action then non-respondents. Yet such engagement is not correlated with political preferences, partisanship, ideology or opinions on a variety of other issues. It is therefore a reasonable assumption that the survey in Sweden is representative of the conflict-related attitudes of migrants, although it may over-represent those more likely to take action with regard to those attitudes. However, the political and social engagement of migrants is not the subject of this survey. In sum, while the analysis cannot be considered definitive, it may offer new and suggestive evidence that contributes to our understanding of the perceptions of migrants after war. Given the nature of previous research, which relies largely on indirect evidence, the data alone are an important contribution to existing knowledge.

\section{Societal Beliefs After War}

Addressing the beliefs that emerge from war is important for peaceful postwar coexistence, which requires establishing relationships built on mutual acceptance and that are both cooperative and sustainable (Ericson 2001; Galtung 2001). Arriving at a common understanding of the past, acknowledging the past experience of other groups and forgiveness provide the starting point for building a common future where trust, positive attitudes and the mutual consideration of needs underpin social relations (Bar-Tal 2000; Hayner 2001; Lederach 2002; Long and Brecke 2003). In essence, the conflictive ethos in society must be replaced by an ethos of peace (Bar-Tal 1998). Central to this process are changes in beliefs about societal goals, the adversary group, the in-group, intergroup relations and the nature of peace (Bar-Tal 2000, 357-359).

To measure prospects for peaceful coexistence, Hayner (2001) suggests assessing how the past is integrated and spoken about between former enemies, if contradictory versions of the past have been reconciled, and if relationships are based on the present rather than the past. I use six indicators to

\footnotetext{
${ }^{9}$ Demographic characteristics of the sample from Sweden do not appear to differ dramatically from those of the population of migrants from the former Yugoslavia living in Sweden. See the section Sample Characteristics below for details.
} 
evaluate the extent to which survey respondents express attitudes embedded in a peace ethos as opposed to a conflict ethos. Answers to these questions represent respondents' views on: how the last war in Bosnia should be defined; the extent to which the participation of their own group should be understood as purely defensive; whether one should forgive those who persecuted their compatriots; the importance they place on their own ethnic belonging; the ideal arrangement of multicultural society in Bosnia, including the role of ethnicity, cultural mixing and intermarriage; and belief in the possibility of peaceful coexistence among Bosniaks, Croats and Serbs in Bosnia unsupervised by external actors.

\section{Control Variables}

To examine whether differences in attitudes between migrants and locals could be the result of differences in the characteristics of the two samples, the regression analysis controls for a set of eleven additional individual background variables. These address the socioeconomic status of respondents as well as their experience of wartime violence and war-related losses.

As mentioned in the theoretical section, individuals with greater personal and social resources are less likely to develop counterproductive coping behaviors. I argue that migration may increase access to such resources, thus decreasing the need to rely on defensive psychological resources such as conflictive beliefs. However, migrants and locals may differ in terms of personal and social resources as a result of selection effects (into either migration to settlement countries or return migration to origin countries). An important assumption in the migration literature is that economic migrants tend to be positively "self-selected" for labor market success in settlement countries (e.g. education level, social networks and an entrepreneurial spirit) (Borjas 1991). While self-selection occurs among political migrants as well, its effect is much less (Chiswick 1999). Political migrants are less likely to return than economic migrants. However, among both groups those most likely to return are the least economically successful (Edin, LaLonde, and Aslund 2000). This is particularly the case when poor labor market conditions in countries of origin discourage the economically successful to return (Borjas 1988). To help account for possible self-selection effects, I control for education level as well as pre-war urban (versus rural) background. In addition, I also control for four additional basic demographic variables: gender, age, marital status and religious participation.

As stated in the literature review, many believe migrants harbor more animosity towards former enemies compared to the local population as a result of their experiences of violence and displacement. Therefore, it is assumed that the displaced are more victimized by war. To help account for this possibility, I employ five indicators aimed at capturing wartime experiences of 
violence and war-related losses: being physically wounded, imprisoned or placed in a camp, participating in fighting units, losing property, and missing a family member as a result of the war. Sample characteristics for these variables are described below.

\section{Sample Characteristics}

In the sample of locals in Bosnia, 54.6 percent of respondents are women. The mean age is 42 years $(S D=16.01) .4 .45$ percent did not complete primary school, 14.2 percent completed at most primary school, 66.36 percent at most secondary school and 15 percent up to one or more years of university studies. 60.61 percent are married $(S D=48.89)$. 2.67 percent do not consider themselves part of a religious community $(S D=16.13)$. Prior to the war, 52.78 percent lived in an urban settlement $(S D=49.94)$.

In the sample of migrants in Sweden, 42.5 percent of respondents are women. The mean age is 44.6 years $(S D=14.1)$. 12.2 percent completed at most primary school, 51.05 percent at most secondary school and 36.75 percent up to one year or more of university studies. ${ }^{10} 67.65$ percent are married $(S D=46.81) .17 .02$ percent do not consider themselves part of a religious community $(S D=36.61)$. Prior to the war, 70.4 percent lived in an urban settlement $(S D=45.67)$. Thus, while the two samples are similar in terms of age and marital status, the sample from Sweden consists of a higher proportion of men and has a higher average education level, a more urban background and is less religious compared to the sample from Bosnia.

During the war, 8.29 percent of respondents in Bosnia report being physically wounded $(S D=27.58)$ and 5.37 percent imprisoned or placed in a camp $(S D=22.55)$. 25.26 percent acknowledge having participated in fighting units $(S D=43.47)$. As a result of the war, 41.85 lost property $(S D=49.35)$ and 32.82 percent are missing a close family member $(S D=46.97)$.

During the war, 7.79 percent of respondents in Sweden report being physically wounded $(S D=26.82)$ and 10.15 percent imprisoned or placed in a camp $(S D=30.23)$. 14.91 percent acknowledge having participated in fighting units $(S D=35.64)$. As a result of the war, 68.60 lost property $(S D=46.44)$ and 41.95 percent are missing a close family member $(S D=49.38)$. Thus, while the two samples are similar with regard to suffering direct bodily harm during the war, many more report being imprisoned, having lost property or missing a family member in the sample from Sweden, while many more report being war veterans in the sample from Bosnia.

\footnotetext{
${ }^{10}$ Compared to the total population of those born in the former Yugoslavia and living in Sweden, men and those with more education are somewhat overrepresented in the sample of migrants. According to Statistics Sweden, 50 percent are women, the mean age is 46 years, 28 percent completed at most primary school, 49 percent at most secondary school and 21 percent up to one year or more of university studies. See the sections "befolkningsstatistik" and "utbildning och forskning" on Statistics Sweden's website (www.scb.se).
} 


\section{Analysis}

Looking at the sample from Sweden, it is that clear the migrant respondents should be considered "conflict-generated" and as including many "persecuted refugees" (Lischer 2005; Lyons 2007). Only 14 percent of the migrants came to Sweden prior to the Bosnian War. The majority ( 57 percent) arrived between the outbreak of fighting in 1992 and the signing of the Dayton Agreement in 1995. 46 percent describe their coming to Sweden as solely for humanitarian reasons and 12 percent solely for political reasons. Migrant respondents thus have ample reason to harbor animosities. However, in the theoretical section I argue migrants should be more likely than locals to rely upon nostalgia to organize past experience. Nostalgia, in turn, may reduce the need for defensive psychological resources such as conflictive beliefs. In Table 1 we see that while Bosniaks, Croats and Serbs are represented equally in both samples, a sizeable proportion of respondents in Sweden in fact identify as Yugoslavs.

Table 1. To which people do you belong? (Percent)

\begin{tabular}{lll}
\hline \hline & BH & SE \\
\hline Bosniak & 33 & 28 \\
Serb & 33 & 26 \\
Croat & 32 & 27 \\
Yugoslav & 0 & 15 \\
Swedish & - & 2 \\
Other & 2 & 2 \\
\hline$N=$ & 1,508 & 707 \\
\hline \hline
\end{tabular}

Table 2. Which of these best expresses your feeling towards your homeland? (Percent)

\begin{tabular}{lll}
\hline \hline & BH & SE \\
\hline Nacionalna Himna Bosne i Hercegovine (Bosnian) & 32 & 20 \\
Boze Pravde (Serbian) & 32 & 13 \\
Lijepa Nasa (Croatian) & 28 & 18 \\
Hej Slaveni (Ex-Yugoslavian) & 8 & 30 \\
Du Gamla, Du Fria (Swedish) & - & 13 \\
Other & 0 & 6 \\
\hline$N=$ & 1,451 & 690 \\
\hline \hline
\end{tabular}

This may not seem surprising at first, since most of the migrant respondents grew up during Yugoslavia's existence. Yet, nearly no one in Bosnia identifies this way. By comparison, in 1989, 14.4 percent of the population of Bosnia expressed Yugoslav self-identification (Sekulic, Massey, and Hodson 1994, 89). At the same time, Table 2 shows that 30 percent of respondents in Sweden express an emotional attachment to Hej Slaveni, the national anthem of the Socialist Federal Republic of Yugoslavia. By comparison, few in Bosnia express the same feeling ( 8 percent). This striking break from the past is 
especially interesting given Bosnia's role in Josip Broz Tito's vision of a united and socialist Yugoslavia, and the view of Bosnian Muslims as a core of its nascent Yugoslav identity (Burić 2010, 228). As a result of new economic, political and social conditions in Bosnia today, Yugoslav identity may no longer appear relevant to the local population.

On the other hand, many migrants in Sweden continue to identify as Yugoslavs and acknowledge emotional ties to Yugoslavia. Part of the reason for this may be that those of mixed marriages are more likely to identify as $\mathrm{Yu}$ goslavs (Sekulic, Massey, and Hodson 1994). Since many feared this group would be disproportionately target by all sides during the war, they were given preference for refuge and asylum in Sweden. However, mixed marriage alone cannot account for the stark contrast between migrants and locals. For migrants, Yugo-nostalgia-with its origins in a socially progressive and welfare-oriented past-may continue to have relevance and meaning for life in the present in Sweden. This, in turn may have a bearing on their conflict-related attitudes.

\section{Survey Responses of Migrants and Locals by Ethnicity}

As stated above, one way to assess the nature of attitudes after war is by looking at the way former enemies speak about the past and the extent to which contradictory versions of the past have been reconciled. Incompatible narratives about the war in Bosnia have existed since its outset. On a fundamental level, the war may be viewed either as an internal armed conflict within the former Yugoslavia or, alternatively, as an aggression of Serbia (or both Serbia and Croatia) on the newly independent state of Bosnia and Herzegovina. Table 3 presents how respondents' define the war. It is clear that among both migrants and locals there remains much disagreement about the nature of the conflict at its most basic level. The vast majority of Bosniaks and Croats in Bosnia view the war as an aggression, while the vast majority of Serbs in Bosnia view it as civil war. The pattern is similar among migrants in Sweden, however within each national group support for the dominant view is less. The difference is most prominent among Bosnian Serbs; only 56 percent of those living in Sweden view the conflict as a civil war, compared with 88 percent of those living in Bosnia. It is also important to note that there is greater uncertainty about the answer to this question among respondents in Sweden. This is especially the case among Yugoslavs but also Bosnian Serbs, 39 percent of whom in Sweden don't know the answer to this question. In Bosnia, only 3 percent of Serbs don't know. In the literature, it is often suggested that migrants have a less complex view of the war. On the contrary, this finding seems to suggest that reality is more clear-cut from the perspective of locals in Bosnia. 
Table 3. According to you, what is the best definition of the last war in Bosnia? (Percent)

\begin{tabular}{lllllllllllll}
\hline \hline & \multicolumn{11}{c}{ National Identity } \\
\cline { 2 - 17 } & \multicolumn{1}{c}{ Bosniak } & \multicolumn{1}{c}{ Serb } & \multicolumn{2}{c}{ Croat } & \multicolumn{2}{c}{ Yugoslav } & \multicolumn{2}{c}{ Other } & \multicolumn{2}{c}{ Total } \\
\cline { 2 - 16 } & BH & SE & BH & SE & BH & SE & BH & SE & BH & SE & BH & SE \\
\hline Aggression & 96 & 73 & 9 & 5 & 70 & 52 & 100 & 7 & 79 & 38 & 59 & 38 \\
Civil war & 3 & 4 & 88 & 56 & 28 & 16 & 0 & 41 & 7 & 24 & 39 & 27 \\
Don't know & 1 & 23 & 3 & 39 & 2 & 32 & 0 & 52 & 14 & 38 & 2 & 35 \\
\hline$N=$ & 503 & 188 & 501 & 176 & 484 & 187 & 2 & 104 & 14 & 29 & 1508 & 690 \\
\hline \hline
\end{tabular}

A related question represents beliefs about the nature of the role of one's own group in the war. I ask about the extent to which respondents agree with the statement "My people fought only wars of defense." This question helps address both views of the past, including acknowledging the suffering of former enemies, as well as the strength of in-group favoritism. Here the difference in attitudes between migrants and locals is again pronounced. Within each national identity group, moving from locals to migrants substantially decreases support for the statement. While 68 percent in Bosnia agree (somewhat or totally) that their people fought only defensive wars, in Sweden only 44 percent do. On the other hand, while 4 percent in Bosnia disagree (somewhat or totally) with this statement, in Sweden 21 percent do. Most striking is the fact that fully 44 percent of Yugoslavs disagree that their people fought only defensive wars. Because so many respondents in Sweden identify themselves as Yugoslavs, this alone represents a substantial increase in peaceful attitudes among migrants. Once again, there is greater uncertainty among respondents in Sweden. In sum, the findings suggest that among migrants there is more agreement about the past, less in-group favoritism and greater acknowledgement of the suffering of other groups.

Table 4. My people fought only wars of defense (Percent)

\begin{tabular}{lcccccccccccc}
\hline \hline & \multicolumn{10}{c}{ National Identity } \\
\cline { 2 - 13 } & \multicolumn{1}{c}{ Bosniak } & \multicolumn{1}{c}{ Serb } & \multicolumn{1}{c}{ Croat } & \multicolumn{1}{c}{ Yugoslav } & Other & \multicolumn{2}{c}{ Total } \\
\cline { 2 - 14 } & BH & SE & BH & SE & BH & SE & BH & SE & BH & SE & BH & SE \\
\hline $\begin{array}{l}\text { Totally } \\
\text { disagree }\end{array}$ & 0 & 4 & 0 & 5 & 1 & 9 & 0 & 24 & 0 & 20 & 1 & 9 \\
$\begin{array}{l}\text { Somewhat } \\
\text { disagree }\end{array}$ & 1 & 3 & 6 & 18 & 3 & 9 & 0 & 20 & 0 & 4 & 3 & 12 \\
$\begin{array}{l}\text { Somewhat } \\
\text { agree }\end{array}$ & 17 & 14 & 34 & 31 & 25 & 22 & 50 & 20 & 29 & 20 & 25 & 22 \\
$\begin{array}{l}\text { Totally agree } \\
\text { Don't know }\end{array}$ & 1 & 73 & 55 & 36 & 70 & 51 & 50 & 14 & 57 & 32 & 68 & 47 \\
\hline$N=$ & 503 & 180 & 501 & 170 & 484 & 170 & 2 & 98 & 14 & 25 & 1508 & 645 \\
\hline \hline
\end{tabular}


In addition to a shared understanding of the past and acknowledgement of the suffering of former enemies, forgiveness is believed to help provide a starting point for establishing positive relationships in the aftermath of war. Table 5 presents respondents views about forgiveness, asking, "Should one forgive those who persecuted your compatriots?" The differences are striking. Across all national groups, about half of the respondents in Bosnia believe that "One should forgive, but never forget." By comparison, 60 percent of respondents in Sweden feel the same way. On the other hand, while 39 percent of respondents in Bosnia believe "One should never forgive," only 24 percent of respondents in Sweden feel the same way. These differences are most salient among Bosniaks: in Bosnia, the majority believes "One should never forgive," while in Sweden the majority believes "One should forgive, but never forget."

Table 5. Should one forgive those who persecuted your compatriots? (Percent)

\begin{tabular}{|c|c|c|c|c|c|c|c|c|c|c|c|c|}
\hline & \multicolumn{10}{|c|}{ National Identity } & & \\
\hline & \multicolumn{2}{|c|}{ Bosniak } & \multicolumn{2}{|c|}{ Serb } & \multicolumn{2}{|c|}{ Croat } & \multicolumn{2}{|c|}{ Yugoslav } & \multicolumn{2}{|c|}{ Other } & \multicolumn{2}{|c|}{ Total } \\
\hline & $\mathrm{BH}$ & $\mathrm{SE}$ & $\mathrm{BH}$ & $\mathrm{SE}$ & $\mathrm{BH}$ & $\mathrm{SE}$ & $\mathrm{BH}$ & $\mathrm{SE}$ & $\mathrm{BH}$ & $\mathrm{SE}$ & $\mathrm{BH}$ & $\mathrm{SE}$ \\
\hline $\begin{array}{l}\text { Yes, one should } \\
\text { forgive and forget }\end{array}$ & 2 & 0 & 7 & 9 & 11 & 5 & 0 & 9 & 7 & 13 & 7 & 6 \\
\hline $\begin{array}{l}\text { One should forgive, } \\
\text { but never forget }\end{array}$ & 41 & 57 & 47 & 59 & 59 & 72 & 50 & 47 & 43 & 57 & 49 & 60 \\
\hline $\begin{array}{l}\text { No, one should never } \\
\text { forgive }\end{array}$ & 55 & 39 & 33 & 22 & 29 & 17 & 50 & 20 & 50 & 10 & 39 & 24 \\
\hline Don't know & 2 & 4 & 13 & 10 & 1 & 6 & 0 & 24 & 0 & 20 & 5 & 10 \\
\hline$N=$ & 503 & 194 & 501 & 182 & 484 & 190 & 2 & 106 & 14 & 30 & 1504 & 708 \\
\hline
\end{tabular}

The question of whether or not to forgive perpetrators is especially salient for the victims of wartime violence. In the theoretical section, I argue that migrants may be better positioned than locals to move on from the traumas of the past. It is therefore interesting to see whether migrant victims perceive forgiveness differently than local victims (not shown in table). I compare responses in Sweden and Bosnia to four questions regarding wartime violence and losses: 1) Were you physically wounded during the war? 2) Were you imprisoned or placed in a camp? 3) Did you lose property as a result of the war? 4) Are you missing a family member as a result of war? Across all four categories, belief in forgiveness is considerably higher among respondents in Sweden. The differences are most striking with regard to victims of physical violence; In Bosnia, 51 percent of those physically wounded believe one should never forgive, while in Sweden 74 percent of those wounded believe one should forgive, but never forget (74 percent). Likewise, compared to the local population belief in forgiveness is more common among migrants who were imprisoned or in a camp (60 percent vs. 48 percent), lost property (66 percent vs. 51 percent) or are missing a family member as a result of the war (63 percent vs. 52 percent). In sum, migrants seem more 
likely to support forgiveness than locals. This relationship is true even among the victims of wartime violence and those who experienced the greatest losses as a result of war.

As mentioned in the theoretical section, violent conflicts escalate through delegitimizing and dehumanizing discourses involving adversarial groups in society. Coping with conflict thus entails reinforcing positive beliefs and emotions pertaining to one's own group. These involves themes such as the legitimacy of group goals, victimhood, and the importance of patriotism and unity (Bar-Tal 1998). Following war, identity politics continue to represent a problem for peace. However, migrants may be less exposed to both the societal conditions and societal communication that reinforce and reflect these beliefs. The Bosnian War pitted three national groups against one another (Bosniaks, Croats and Serbs). An important question is thus to what extent migrants and locals differ in terms of the importance they ascribe to national identity. Table 6 presents answers to the question "How would you describe your relation to your own national belonging?" Again, the relationship is clear; within each national group, respondents in Sweden attach less importance to their own national belonging. The difference is particularly large among Serbs: in Bosnia, nearly two-thirds feel their national belonging is an important part of their lives, while in Sweden two-thirds either accept it but do not think about it much or find it irrelevant. In addition, it is remarkable, though not surprising, that 40 percent of Yugoslavs in Sweden feel national belonging is irrelevant.

Table 6. How would you describe your relation to your own national belonging? (Percent)

\begin{tabular}{|c|c|c|c|c|c|c|c|c|c|c|c|c|}
\hline & \multicolumn{10}{|c|}{ National Identity } & \multirow{2}{*}{\multicolumn{2}{|c|}{ Total }} \\
\hline & \multicolumn{2}{|c|}{ Bosniak } & \multicolumn{2}{|l|}{ Serb } & \multicolumn{2}{|c|}{ Croat } & \multicolumn{2}{|c|}{ Yugoslav } & \multicolumn{2}{|c|}{ Other } & & \\
\hline & $\mathrm{BH}$ & $\mathrm{SE}$ & $\mathrm{BH}$ & SE & $\mathrm{BH}$ & SE & $\mathrm{BH}$ & SE & $\mathrm{BH}$ & SE & $\mathrm{BH}$ & $\mathrm{SE}$ \\
\hline $\begin{array}{l}\text { National belonging is irrele- } \\
\text { vant }\end{array}$ & 4 & 6 & 3 & 5 & 5 & 6 & 50 & 40 & 36 & 46 & 4 & 13 \\
\hline $\begin{array}{l}\text { I accept it but don't think of it } \\
\text { much }\end{array}$ & 42 & 55 & 35 & 61 & 39 & 49 & 50 & 56 & 55 & 39 & 39 & 54 \\
\hline $\begin{array}{l}\text { National belonging is an } \\
\text { important part of my life }\end{array}$ & 54 & 39 & 62 & 34 & 56 & 45 & 0 & 4 & 9 & 15 & 57 & 33 \\
\hline$N=$ & 495 & 192 & 492 & 178 & 480 & 188 & 2 & 106 & 11 & 26 & 1483 & 691 \\
\hline
\end{tabular}

Examining support for ethnic mixing and intermarriage also offers insight into attitudes towards former adversaries. This also helps to ascertain the extent to which relationships among groups are characterized by trust, positive attitudes and the mutual consideration of needs. Table 7 presents respondents' beliefs about the ideal societal arrangement for Bosnia. Once again, within each national group the difference between migrant and local respondents is stark. 66 percent of Bosniaks in Sweden as opposed to 28 
percent in Bosnia prefer "A society in which ethnic belonging is irrelevant. Individuals socialize freely, and mixed marriages are very common." 63 percent of Serbs in Sweden answer the same way, but only 14 percent in Bosnia do so. 47 percent of Croats agree, while only 16 percent in Bosnia do. Finally, fully 88 percent of Yugoslavs in Sweden feel the same way. In sum, while nearly two-thirds of the respondents in Sweden choose this option, in Bosnia the corresponding number is 21 percent. Moreover, the most common choice among respondents in Bosnia is at the opposite end of the spectrum, where "Groups don't mix, each protects its own culture, and there are no mixed marriages."

Table 7. In BH live people of different nationalities. According to you, what would be the ideal societal arrangement? (Percent)

\begin{tabular}{|c|c|c|c|c|c|c|c|c|c|c|c|c|}
\hline & \multicolumn{12}{|c|}{ National Identity } \\
\hline & \multicolumn{2}{|c|}{ Bosniak } & \multicolumn{2}{|c|}{ Serb } & \multicolumn{2}{|c|}{ Croat } & \multicolumn{2}{|c|}{ Yugoslav } & \multicolumn{2}{|c|}{ Other } & \multicolumn{2}{|l|}{ Total } \\
\hline & $\mathrm{BH}$ & $\mathrm{SE}$ & $\mathrm{BH}$ & SE & $\mathrm{BH}$ & SE & $\mathrm{BH}$ & $\mathrm{SE}$ & $\mathrm{BH}$ & SE & $\mathrm{BH}$ & SE \\
\hline $\begin{array}{l}\text { A society in which ethnic } \\
\text { belonging is irrelevant. } \\
\text { Individuals socialize } \\
\text { freely, and mixed marria- } \\
\text { ges are very common }\end{array}$ & 28 & 66 & 14 & 63 & 16 & 47 & 100 & 88 & 91 & 86 & 21 & 64 \\
\hline $\begin{array}{l}\text { Groups protect their own } \\
\text { culture, but there are some } \\
\text { mixed marriages }\end{array}$ & 42 & 25 & 31 & 23 & 38 & 29 & 0 & 11 & 0 & 14 & 36 & 23 \\
\hline $\begin{array}{l}\text { Groups don't mix, each } \\
\text { protects its own culture, } \\
\text { and there are no mixed } \\
\text { marriages }\end{array}$ & 30 & 9 & 55 & 14 & 46 & 24 & 0 & 1 & 9 & 0 & 43 & 13 \\
\hline$N=$ & 475 & 192 & 485 & 181 & 477 & 185 & 2 & 107 & 11 & 29 & 1453 & 700 \\
\hline
\end{tabular}

An additional way to measure trust between former adversaries is to ask whether they believe they can coexist without returning to war. Table 8 presents responses to the question "Do you think Bosniaks Croats and Serbs in Bosnia can live peacefully together without international supervision, or did the war make peaceful coexistence impossible?" Support for the statement "The war has made peaceful coexistence impossible" is about the same among migrants and locals. However, while 68 percent of respondents in Bosnia believe "They can live together without international supervision," only 41 feel this way in Sweden. The difference between migrants and locals is explained largely by greater uncertainty among migrants, 33 percent of whom simply "Don't know" whether peaceful coexistence is possible. By comparison, only 3 percent of locals don't know.

Belief in the possibility of coexistence among the respondents in Bosnia certainly reflects a positive outcome in terms of reconciliation. However, more pessimism among migrants in relation to this question alone does not 
necessarily reflect more conflictive attitudes. Experiencing peaceful coexistence in Bosnia in daily life may help reduce uncertainty among locals. Respondents living in Sweden are asked to reveal their attitudes not about themselves but about the capacity of the local population in Bosnia, and on this count they remain more uncertain.

As a whole, these findings suggest that migrants indeed hold more peaceful attitudes than locals after war. This result holds true even when controlling for national identity. Migrants are external to the local situation in which societal conditions and social communication reinforce a conflictive ethos, and are more likely to draw upon Yugo-nostalgia as a source of identity. Moreover, to the extent that migration increases access to coping resources, it may reduce reliance on defensive psychological resources such as exclusionary attitudes and the derogation of out-groups.

Table 8. Do you think Bosniaks, Croats and Serbs in Bosnia can live peacefully together without international supervision, or did the war make peaceful coexistence impossible? (Percent)

\begin{tabular}{|c|c|c|c|c|c|c|c|c|c|c|c|c|}
\hline \multicolumn{13}{|c|}{ National Identity } \\
\hline & \multicolumn{2}{|c|}{ Bosniak } & \multicolumn{2}{|c|}{ Serb } & \multicolumn{2}{|c|}{ Croat } & \multicolumn{2}{|c|}{ Yugoslav } & \multicolumn{2}{|c|}{ Other } & \multicolumn{2}{|c|}{ Total } \\
\hline & BH & SE & $\mathrm{BH}$ & SE & $\mathrm{BH}$ & SE & $\mathrm{BH}$ & SE & $\mathrm{BH}$ & SE & $\mathrm{BH}$ & SE \\
\hline $\begin{array}{l}\text { They can live together } \\
\text { without international } \\
\text { supervision }\end{array}$ & 56 & 46 & 77 & 42 & 70 & 32 & 100 & 47 & 64 & 34 & 68 & 41 \\
\hline $\begin{array}{l}\text { War has made peaceful } \\
\text { coexistence impossible }\end{array}$ & 35 & 26 & 19 & 18 & 22 & 38 & 0 & 20 & 29 & 7 & 25 & 26 \\
\hline Don't know & 9 & 28 & 4 & 40 & 8 & 30 & 0 & 33 & 7 & 55 & 7 & 33 \\
\hline$N=$ & 503 & 193 & 501 & 182 & 484 & 187 & 2 & 104 & 14 & 29 & 1508 & 701 \\
\hline
\end{tabular}

\section{Regression Analysis}

As stated in the data and method section, it is conceivable that differences in the attitudes of migrants and locals after war are the result of differences in the characteristics of the two samples. In this section, I control for a set of background variables that address socioeconomic status, wartime experiences and war-related losses. First, in Table 9 I present bivariate regressions in which eight separate attitudes about war are regressed upon a dichotomous variable indicating the respondent is a migrant (versus a local). Next, I include the controls. The mean of each dichotomous dependent variable is presented in order to easily interpret the effects of being a migrant. The first three regressions analyze Bosniaks, Croats and Serbs separately in order to measure the effect of being a migrant on support for the definition of the war that is dominant within their own national group. The other five regressions include all groups. 


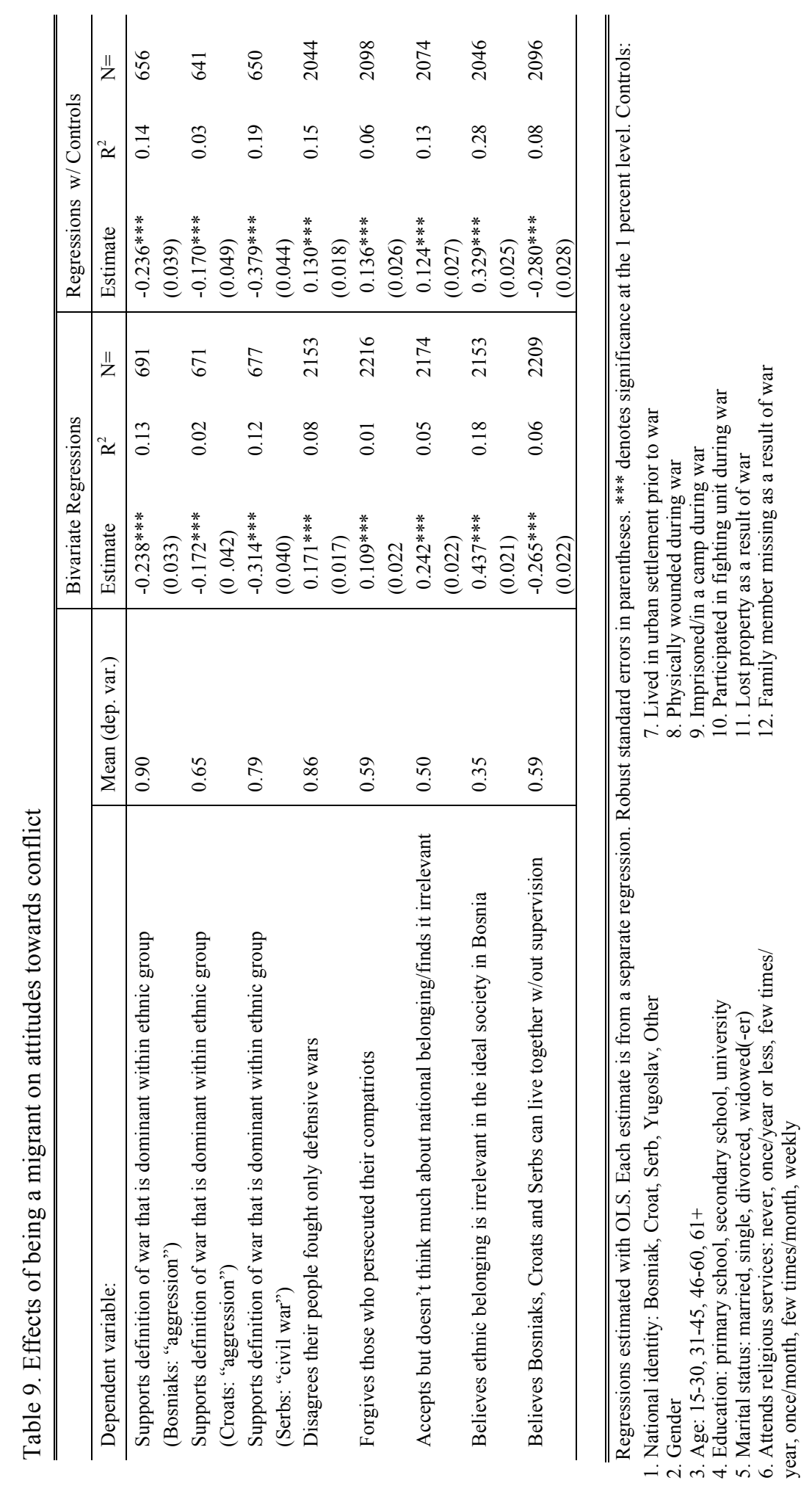


In general, the regressions indicate that the effects of being a migrant on attitudes about war are highly significant, stable, substantively large andapart from expressing less optimism about peaceful coexistence in Bosniain the expected direction. Migrants show less support for definitions of the war that are dominant in their own national group, are more likely to disagree that their people fought only defensive wars, are more willing to forgive perpetrators, attach less importance to their own national belonging and are more positive towards ethnic mixing and intermarriage among Bosniaks, Croats and Serbs in Bosnia. For the most part, introducing controls has little effect on the estimates. Finally, the estimates tend to be large. For example, moving from locals to migrants increases by 32.9 percentage points support for the view that, ideally, ethnic belonging would be irrelevant in Bosnian society and that ethnic mixing and intermarriage would occur unencumbered. This represents nearly a two-fold increase in peaceful attitudes in comparison to the mean (35 percent).

\section{Conclusions}

Attitudinal research has largely overlooked migrants originating from, but external to, conflict-affected countries. This article takes up an important but largely unexamined assumption in the literature: that migrants harbor more conflictive attitudes than locals after war. Previous literature tends to portray migrants as extreme, even though we lack the micro-level data necessary to examine their attitudes directly. Rather than relying on indirect evidence, I analyze new data from simultaneous surveys conducted in Sweden and Bosnia in 2010. As a whole, the empirical analysis supports the paper's novel theoretical approach. Migration may provide an exit from the spiral of local economic and political conditions and societal communication that sustain conflictive beliefs after war. To manage the stress of acculturation and displacement, migrants may draw upon nostalgia. However, rather than reinforcing a sense of exile and victimization among conflict-generated migrants, nostalgia may under certain conditions increase their ability to move on after crisis. To the extent that migrants have greater access to coping resources, they have less need to rely on defensive psychological measures such as conflictive beliefs.

What are the scope conditions of this analysis? In certain settlement contexts, migrants may actually have access to fewer coping resources than back home. Examples may include cross-border refugee camps. Although such camps may provide respite from worsening conditions in the homeland, in some cases refugee crises continue long after the war ends. Moreover, there are instances in which the ideological climate of refugee camps and settlement countries reinforce the conflictive ethos. Examples might include Pashtun refugees in Pakistan along the border to Afghanistan, or the political 
exiles from Eastern block countries that settled in the West during the height of the Cold War (e.g. Cubans in United States).

On the other hand, conditions in origin countries may also change for the better. Not all post-war societies are caught in "no war, no peace" situations, and in some cases major crises bring about social revolutions that overturn exclusionary ideologies. For example, following the Second World War dramatic social revolutions swept across Europe. In the case of Bosnia, after the fascist Ustaša regime of the Independent State of Croatia fell to the partisan movement the territory became part of Yugoslavia-a modernizing and multiethnic state governed according to Josip Broz Tito's principles of "brotherhood and unity". In the Croatian diaspora, however, certain networks of political exiles continued to nurture fascist and nationalist ideologies during the Cold War (Hockenos 2003). These very same groups contributed to ethnic mobilization and the wars of Yugoslav Succession during the 1990s. Until now, the mistake has been to generalize from observations about these groups to, for example, Croatian migrants as a whole or migrants more generally. ${ }^{11}$ Such considerations provide an excellent starting point for future comparative research in this area.

However, a common strand of thought since the founding of the Chicago School has been that migrants are socially marginalized and psychologically vulnerable, which has been linked to political intolerance (Halperin, CanettiNisim, and Hirsch-Hoefler 2009). This paper thus offers a unique contribution to our understanding of political attitudes after war. Under certain conditions, migration may promote inclusive and reconciliatory attitudes by improving access to coping resources and providing an exit from detrimental wartime and post-war conditions in origins countries.

\section{References}

Acton, John Dahlberg. 1967. Essays in the Liberal Interpretation of History. Chicago: University of Chicago Press.

Adamson, Fiona B. 2005. Globalisation, Political Mobilisation, and Networks of Violence. Cambridge Review of International Affairs 18 (1): 31-49.

Adamson, Fiona B. 2006. Crossing Borders: International Migration and National Security. International Security 31 (1): 165-199.

Adelman, Howard. 1998. Why Refugee Warriors are Threats. The Journal of Conflict Studies XVIII (1): 49-69.

Althaus, Scott L., Brittany H. Bramlett, and James G. Gimpel. 2012. When War Hits Home : The Geography of Military Losses and Support for War in Time and Space. Journal of Conflict Resolution 56 (3): 382-412.

\footnotetext{
${ }^{11}$ This has implications for nostalgia as a psychological mechanism, which may have different outcomes for political attitudes depending on historical context. In some cases, nostalgia for the past may uplift exclusionary ideologies.
} 
Anderson, Benedict. 1998. "Long Distance Nationalism." In The Spectre of Comparisons: Nationalism, Southeast Asia and the World. London: Verso. 5874.

Anderson, Mary B. 1999. Do No Harm: How Aid Can Support Peace--or War. Boulder, CO: Lynne Rienner.

Antonovsky, Aaron. 1979. Health, stress, and coping. 1st ed of The Jossey-Bass social and behavioral science series. San Francisco: Jossey-Bass Publishers.

Bar-Tal, Daniel. 1998. Societal beliefs in times of intractable conflict: The Israeli case. International Journal of Conflict Management 9 (1): 22-50.

Bar-Tal, Daniel. 2000. From Intractable Conflict Through Conflict Resolution to Reconciliation: Psychological Analysis. Political Psychology 21 (2): 351-365.

Bar-Tal, Daniel. 2000. Shared beliefs in a society: Social psychological analysis. Thousand Oaks, CA: Sage.

Bar-Tal, Daniel. 2007. Sociopsychological Foundations of Intractable Conflicts. American Behavioral Scientist 50 (11): 1430-1453.

Becker, Ernest. 1973. The denial of death. New York, NY: Free Press.

Berinsky, Adam J. 2008. "Survey Non-Response." In The SAGE Handbook of Public Opinion Research, eds. Wolfgang Donsbach and Michael W. Traugott. London: SAGE. 309-321.

Bigombe, Betty, Paul Collier, and Nicholas Sambanis. 2000. Policies for Building Post-Conflict Peace. Journal of African Economies 9 (3): 323-348.

Blattman, Christopher, and Edward Miguel. 2010. Civil War. Journal of Economic Literature 48 (1): 3-57.

Bock-Luna, Birgit 2007. The Past in Exile: Serbian Long-Distance Nationalism and Identity in the Wake of the Third Balkan War. New Brunswick: Transaction Publishers.

Borjas, George J. 1988. Immigration and Self-selection. NBER. 2566.

Borjas, George J. 1991. "Immigration, Trade and the Labor Market." In, eds. John M. Abowd and Richard B. Freeman. Chicago: University of Chicago Press. 29 76.

Brinkerhoff, Jennifer M. 2006. Digital Diasporas and Conflict Prevention: The Case of Somalinet.com. Review of International Studies 32: 25-47.

Brounéus, Karen. 2010. The Trauma of Truth Telling: Effects of Witnessing in the Rwandan Gacaca Courts on Psychological Health. Journal of Conflict Resolution 54 (3): 408-437.

Brounéus, Karen. 2008. Truth-Telling as Talking Cure? Insecurity and Retraumatization in the Rwandan Gacaca Courts. Security Dialogue 39 (1): 5576.

Brubaker, Roger. 2005. The 'diaspora' diaspora. Ethnic and Racial Studies 28 (1): 119.

Burić, Fedja. 2010. "Dwelling on the Ruins of Socialist Yugoslavia: Being Bosnian by Remembering Tito." In Post-Communist Nostalgia, eds. Maria Todorova and Gille Zsuzsa. New York: Berghahn Books. 227-243.

Byman, Daniel L., Peter Chalk, Bruce Hoffman, William Rosenau, and David Brannan. 2001. Trends in Outside Support for Insurgent Movements. Santa Monica, CA: RAND Corporation.

Caarls, Kim, Sonja Fransen, and Ruerd Ruben. 2012. Can Migratory Contacts and Remittances Contribute to Reconciliation and Reconstruction in Rwanda? International Migration Online First: 1-20.

Canetti-Nisim, Daphna, Eran Halperin, Keren Sharvit, and Stevan E. Hobfoll. 2009. A New Stress-Based Model of Political Extremism. Journal of Conflict Resolution 53 (3): 363-389. 
Chiswick, Barry R. 1999. Are Immigrants Favorably Self-Selected? American Economic Review 89 (2): 181-185.

Cochrane, Feargal. 2007. Irish-America, the End of the IRA's Armed Struggle and the Utility of 'Soft Power'. Journal of Peace Research 44 (2): 215-231.

Cochrane, Feargal, Bahar Baser, and Ashok Swain. 2009. Home Thoughts from Abroad: Diasporas and Peace-Building in Northern Ireland and Sri Lanka. Studies in Conflict and Terrorism 32 (8): 681-704.

Collier, P. 2000. Economic Causes of Civil Conflict and their Implications for Policy. Washington, DC: World Bank.

Collier, Paul, Lani Elliott, Håvard Hegre, Anke Hoeffler, Marta Reynal-Querol, and Nicholas Sambanis. 2003. Breaking the Conflict Trap: Civil War and Development Policy. Oxford: Oxford University Press.

Collier, Paul, and Anke Hoeffler. 2004. Greed and Grievance in Civil War. Oxford Economic Papers 56 (4): 563-595.

Collier, Paul, and Anke Hoeffler. 2006. "The Political Economy of Secession." In Negotiating Self-Determination, eds. Hurst Hannum and Eileen F. Babbitt. Lanham, MD: Lexington Books.

Collier, Paul, and Anke Hoeffler. 2007. "Civil War." In Handbook of Defence Economics, eds. Todd Sandler and Keith Hartley. Amsterdam: North-Holland.

Davis, Fred. 1977. Nostalgia, Identity, and the Current Nostalgia Wave. Journal of Popular Culture 11: 414-425.

Davis, Fred. 1979. Yearning for yesterday: A Sociology of Nostalgia. New York: Free Press.

Duffield, Mark. 2001. Global Governance and the New Wars: The Merging of Development and Security. London: Zed Books.

Edin, Per-Anders, Robert J. LaLonde, and Olof Åslund. 2000. Emigration of immigrants and measures of immigrant assimilation: Evidence from Sweden. Swedish Economic Policy Review 7: 163-204.

Ericson, Maria. 2001. Reconciliation and Search for a Shared Moral Landscape: An Exploration Based on Study of Northern Ireland and South Africa. Frankfurt am Main and New York: P. Lang.

Fair, C. Christine. 2005. Diaspora Involvement in Insurgencies: Insights from the Khalistan and Tamil Eelam Movements. Nationalism and Ethnic Politics 11 (1): 125-156.

Fearon, James D. 2011. Governance and Civil War Onset. Stanford, CA: Stanford University.

Galtung, Johan. 2001. "After Violence, Reconstruction, Reconciliation, and Resolution: Coping with Visible and Invisible Effects of War and Violence." In Reconciliation, Justice, and Coexistence: Theory and Practice, ed. Mohammed Abu-Nimer: Lexington Books. 3-24.

Ghobarah, Hazem Adam, Paul Huth, and Bruce Russett. 2003. Civil Wars Kill and Maim People-Long After the Shooting Stops. American Political Science Review 97 (2): 189-202.

Gibson, James L. 2004. Does Truth Lead to Reconciliation? Testing the Causal Assumptions of the South African Truth and Reconciliation Process. American Journal of Political Science 48 (2): 201-217.

Gibson, James L., Jeffrey Sonis, and Sokhom Hean. 2010. Cambodians' Support for the Rule of Law on the Eve of the Khmer Rouge Trials. The International Journal of Transitional Justice 4 (3).

Golan, Galia, and Adir Gal. 2009. "Globalization and the Transformation of Conflict." In Conflict Transformation and Peacebuilding: Moving From 
Violence to Sustainable Peace, eds. Bruce W. Dayton and Louise Kriesberg. New York: Routledge.

Halperin, Eran, and Daniel Bar-Tal. 2011. Socio-psychological barriers to peace making: An empirical examination within the Israeli Jewish Society. Journal of Peace Research 48 (5): 637-651.

Halperin, Eran, Daphna Canetti-Nisim, and Sivan Hirsch-Hoefler. 2009. The central role of group-based hatred as an emotional antecedent of political intolerance: Evidence from Israel. Political Psychology 30 (1): 93-123.

Harpviken, Kristian Berg. 2009. Social Networks and Migration in Wartime Afghanistan. New York, NY: Palgrave-Macmillan.

Hayner, Pracilla B. 2001. Unspeakable Truth. Confronting State Terror and Atrocity. New York and London: Routledge.

Hobfoll, Stevan E., Daphna Canetti-Nisim, and Robert J. Johnson. 2006. Exposure to Terrorism, Stress-Related Mental Health Symptoms, and Defensive Coping Among Jews and Arabs in Israel. Journal of Consulting and Clinical Psychology 74 (2): 207-218.

Hockenos, Paul. 2003. Homeland calling: Exile patriotism and the Balkan Wars. Ithaca, NY: Cornell University Press.

Hoeffler, Anke. 2012. "On the Causes of Civil War." In The Oxford Handbook of the Economics of Peace and Conflict, eds. Michelle R. Garfinkel and Stergios Skaperdas. Oxford: Oxford University Press. 179-204.

Holbrook, Allyson L., Jon A. Krosnick, and Alison Pfent. 2007. "The Causes and Consequences of Response Rates in Surveys by the News Media and Government Contractor Survey Research Firms." In Advances in Telephone Survey Methodology, eds. James M. Lepkowski, Clyde Tucker, J. Michael Brick, Edith D. de Leeuw, Lilli Japec, Paul J. Lavrakas, Michael W. Link and Roberta L. Sangster. New York: Wiley. 499-528.

Horst, Cindy. 2008. The Transnational Political Engagement of Refugees: Remittance Sending Practices amongst Somalis in Norway. Conflict, Security \& Development 8 (3): 317-339.

Ignatieff, Michael 2001. "The Hate Stops Here." In The Globe and Mail.

Iyer, Aarti, and Jolanda Jetten. 2011. What's Left Behind: Identity Continuity Moderates the Effect of Nostalgia on Well-Being and Life Choices. Journal of Personality and Social Psychology 101 (1): 94-108.

Jaffrelot, Christophe, and Ingrid Therwath. 2007. The Sangh Parivar and the Hindu Diaspora in the West: What Kind of "Long-Distance Nationalism"? International Political Sociology 7 (1): 278-295.

Janoff-Bulman, Ronnie. 1992. Shattered assumptions: Towards a new psychology of trauma. New York: Free Press.

Juhl, Jacob, Clay Routledge, Jamie Arndt, Constantine Sedikides, and Tim Wildschut. 2010. Fighting the future with the past: Nostalgia buffers existential threat. Journal of Research in Personality 44 309-314.

Kaldor, Mary. 2001. New and Old Wars: Organised Violence in a Global Era. Oxford: Polity Press.

Kaldor, Mary. 2004. Nationalism and Globalisation. Nations and Nationalism 10 (1/2): 161-177.

Kaldor-Robinson, Joshua. 2002. The Virtual and the Imaginary: The Role of Diasporic New Media in the Construction of a National Identity during the Break-up of Yugoslavia. Oxford Development Studies 30 (2): 177-187.

Kelman, Herbert C. 1997. "The Social-Psychological Dimensions of International Conflict." In Peacemaking in International Conflict: Methods and Techniques, 
ed. William I. Zartman and J. Lewis Rasmussen. Washington, DC: United States Institute of Peace. 191-238.

Kostić, Roland. 2007. Ambivalent Peace: External Peacebuilding, Threatened Identity and Reconciliation in Bosnia and Herzegovina. Department of Peace and Conflict Research.

Kostić, Roland. 2012. Transitional justice and reconciliation in Bosnia-Herzegovina: Whose memories, whose justice? Sociologija 54 (4): 649-666.

Lederach, John Paul. 2002. Building Peace: Sustainable Reconciliation in Divided Societies. Washington, DC: United States Institute of Peace.

Lischer, Sarah Kenyon. 2005. Dangerous Sanctuaries: Refugee Camps, Civil War, and the Dilemmas of Humanitarian Aid. Ithaca, N.Y: Cornell University Press.

Lischer, Sarah Kenyon. 2008. Security and Displacement in Iraq. International Security 33 (2): 95-119.

Long, Willian J., and Peter Brecke. 2003. War and Reconciliation: Reasons and Emotions in Conflict Resolution. Massachusetts, London, England: The MIT Press.

Lyons, Terrence. 2006. "Diasporas and Homeland Conflict." In Globalization, Territoriality, and Conflict, eds. Miles Kahler and Barbara F. Walter. Cambridge: Cambridge University Press.

Lyons, Terrence. 2007. Conflict-Generated Diasporas and Transnational Politics in Ethiopia. Conflict, Security, and Development 7 (4): 529-549.

Mac Ginty, Roger 2006. No War, No Peace: The Rejuvenation of Stalled Peace Processes and Peace Accords. London: Palgrave-Macmillan.

Newman, David. 2006. "The Resilience of Territorial Conflict in an Era of Globalization." In Territoriality and Conflict in an Era of Globalization, eds. Miles Kahler and Barbara F. Walter. Cambridge: Cambridge University Press.

Orjuela, Camilla. 2008. Distant warriors, distant peace workers? Multiple diaspora roles in Sri Lanka's violent conflict. Global Networks 8 (4): 436-452.

Pew Research Center. 2012. Assessing the Representativeness of Public Opinion Surveys. Washington, DC: Pew Research Center.

Pham, Phuong N., Patrick Vinck, Eric Stover, Marieke Wierda, A.R. Moss, and Richard Bailey. 2007. When the War Ends: A Population-Based Survey on Attitudes about Peace, Justice, and Social Reconstruction in Northern Uganda. Berkeley, CA: Human Rights Center, University of California.

Routledge, Clay, Jamie Arndt, Constantine Sedikides, and Tim Wildschut. 2008. A blast from the past: The terror management function of nostalgia. Journal of Experimental Social Psychology 44: 132-140.

Routledge, Clay, Jamie Arndt, Tim Wildschut, Constantine Sedikides, Claire M. Hart, Jacob Juhl, Ad J. J. M. Vingerhoets, and Wolf Scholtz. 2011. The Past Makes the Present Meaningful: Nostalgia as an Existential Resource. Journal of Personality and Social Psychology 101: 638-652.

Salehyan, Idean. 2006. "Rebels Without Borders: State Boundaries, Transnational Opposition, and Civil Conflict." Doctoral Dissertation University of California.

Salehyan, Idean. 2007. Refugees and the Study of Civil War. Civil Wars 9 (2): 127141.

Salehyan, Idean. 2007. Transnational Rebels: Neighboring States as Sanctuary for Rebel Groups. World Politics 59 (January): 217-242.

Salehyan, Idean. 2009. Rebels without borders. Ithaca, NY: Cornell University Press.

Salehyan, Idean, and Kristian Skrede Gleditsch. 2006. Refugee Flows and the Spread of Civil War. International Organization 60 (2): 335-366. 
Sambanis, Nicholas. 2002. A Review of Recent Advances and Future Directions in the Quantitative Literature on Civil War. Defence and Peace Economics 13 (3): 215-243.

Sedikides, Constantine, Tim Wildschut, Jamie Arndt, and Clay Routledge. 2008. Nostalgia: Past, Present, and Future. Current Directions in Psychological Science 17 (5): 304-307.

Sedikides, Constantine, Tim Wildschut, Lowell Gaertner, Clay Routledge, and Jamie Arndt. 2008. "Nostalgia as an enabler of self-continuity." In Self continuity: Individual and collective perspectives, ed. Fabio Sani. New York: Psychology Press. 227-239.

Sedikides, Constantine, Tim Wildschut, Clay Routledge, Jamie Arndt, and Xinyue Zhou. 2009. "Buffering Acculturative Stress and Facilitating Cultural Adaptation Nostalgia as a Psychological Resource." In Understanding Culture: Theory, Research and Application, ed. Chi-yue Chiu Robert S. Wyer, and Yingyi Hong. New York, NY: Psychology Press. 361-378.

Sekulic, Dusko, Garth Massey, and Randy Hodson. 1994. Who Were the Yugoslavs? Failed Sources of a Common Identity in the Former Yugoslavia. American Sociological Review 59 (February): 83-97.

Shain, Yossi. 2007. Kinship and Diasporas in International Affairs. Ann Arbor: University of Michigan Press.

Sheffer, Gabriel. 2003. Diaspora Politics. At Home Abroad. Cambridge: Cambridge University Press.

Smith, Anthony D. . 1986. "The Ethnic Origins of Nations." In. Oxford: Blackwell.

Smith, Hazel, and Paul Stares. 2007. Diasporas in Conflict: peace-makers or peacewreckers? Tokyo: United Nations University Press.

Solomon, Sheldon, Jeff Greenberg, and Tom Pyszczynski. 2000. Pride and prejudice: fear of death and social behaviour. Current Directions in Psychological Science 9 (6): 200-204.

Stedman, Stephen J., and Fred Tanner. 2003. Refugee manipulation: war, politics, and the abuse of human suffering. Washington, DC: Brookings Institution.

Tarrow, Sidney. 2007. Inside Insurgencies: Politics and Violence in an Age of Civil War. Persepctives on Politics 5 (3): 587-600.

Taylor, Shelley E. 1983. Adjustment to threatening events: A theory of cognitive adaptation. American Psychologist 38: 1161-1173.

Tedeschi, Richard G., and Lawrence G. Calhoun. 2004. Posttraumatic Growth: Conceptual Foundations and Empirical Evidence. Psychological Inquiry 15 (1): $1-18$.

Thoms, Oskar N.T., James Ron, and Roland Paris. 2010. State-Level Effects of Transitional Justice: What Do We Know? The International Journal of Transitional Justice 4 (3): 329-354.

Turner, Simon. 2008. The waxing and waning of the political field in Burundi and its diaspora. Ethnic and Racial Studies 31 (4): 742-765.

Valenta, Marko, and Sabrina P. Ramet. 2011. "Bosnian Migrants: An Introduction." In The Bosnian Diaspora: Integration in Transnational Communities, eds. Marko Valenta and Sabrina P. Ramet. Farnham: Ashgate. 1-23.

Van Hear, Nick. 1998. New Diasporas: The mass exodus, dispersal and regrouping of migrant communities. London: UCL Press.

Vess, Matthew, Jamie Arndt, Clay Routledge, Constantine Sedikides, and Tim Wildschut. 2012. Nostalgia as a Resource for the Self. Self and Identity 11 (3): 273-284.

Wayland, Sarah. 2004. Ethnonationalist networks and transnational opportunities: the Sri Lankan Tamil diaspora. Review of International Studies 30 (3): 405-426. 
Wennmann, Achim. 2007. The Political Economy of Conflict Financing: A Comprehensive Approach Beyond Natural Resources. Global Governance 13: 427-44.

Wildschut, Tim, Constantine Sedikides, Jamie Arndt, and Clay Routledge. 2006. Nostalgia: Content, triggers, functions. Journal of Personality and Social Psychology 91: 975-993.

Zhou, Xinyue, Tim Wildschut, Constantine Sedikides, Kan Shi, and Cong Feng. 2012. Nostalgia: The Gift That Keeps on Giving. Journal of Consumer Research 39 (June): Online First.

Zolberg, Aristide, Astri Suhrke, and Sergio Aguayo. 1989. Escape from Violence: Conflict and the Refugee Crisis in the Developing World. New York, NY: Oxford University Press. 